\title{
ГОСПОДАРСЬКА ДІЯЛЬНІСТЬ БУДІВЕЛЬНОЇ ОРГАНІЗАЦЇ̈ ТА ШЛЯХИ ЇЇ УДОСКОНАЛЕННЯ
}

\author{
Корнило І. М., Гнип О. П.
}

\section{ВСТУП}

Перехід на ринкові відносини, відмова від планового управління будівельною галуззю вимагають вироблення принципово нового механізму управління будівельними організаціями, що забезпечує їм ефективне функціонування в умовах ринку.

Проте економічний стан будівельних організацій свідчить про істотний розрив між їхнім реальним станом і моделлю конкурентоспроможності організації ринкового типу. У зв'язку з цим на сучасному етапі повинна відбутися зміна філософії господарювання, придбання навиків підприємницької поведінки, подолання негативного впливу зовнішнього середовища і внутрішніх суперечностей.

Щоб забезпечити собі тривале життя, організація повинна мати чітку певну мету, відчуття напряму і уявлення про те, які засоби ій потрібні. Все це організація одержує за допомогою стратегічного управління. Воно вимагає від керівників розуміння суті стратегії, використовування прийомів стратегічного управління і розроблення стратегічних планів. Абсолютно очевидно, що стратегія повинна змінюватися і пристосовуватися до умов, які змінюються.

Головна задача стратегії - найвигіднішим чином вписатися в навколишнє середовище і відповідати йому.

Стратегія визначає, куди організація хоче йти, щоб досягти своєї мети і виконати свою місію. Вона створює обмежувачі, що відображають особливості й напрям діяльності організації, і задає межі вибору, тобто визначає, чим організація хоче стати на майбутній тривалий період часу.

Якщо озирнутися назад, на минулу діяльність нашої фірми, то місію можна визначити як зміцнення оборонної здатності країни, враховуючи загальну політику держави.

У нинішніх економічних і політичних умовах, що змінилися, для визначення місії повинен бути вироблений інший підхід. Це головне питання для будь-якої фірми і досить непростий для нашої.

Місію можна спробувати сформулювати, як готовність у будь-яких умовах виконати насамперед державне замовлення, а також замовлення, що фінансується 3 інших джерел, будь-якого ступеня складності, в мінімальні терміни, з належною якістю. 
Виходячи 3 певної місії фірми, повинні бути визначені довгострокові та середньострокові цілі. Загальні цілі відображають концепцію розвитку фірми і розробляються на тривалу перспективу.

Натепер глобальною метою $\epsilon$ зміна господарської діяльності організації і перетворення ії в надійну систему, при цьому повинна бути забезпечена фінансова стійкість та економічне зростання організації.

Специфічні особливості товару, що випускається будівельною організацією, впливають на процеси реформування будівельних організацій в умовах переходу до ринку.

До особливостей будівельної продукції відносяться:

- нерухомість будівельної продукції і необхідність відведення земельної ділянки для будівництва об'єкту;

- значний вплив чинника часу на техніко-економічні показники продукції;

- вплив природно-кліматичних умов, різноманіття виробничих зв'язків, велика складність, висока вартість, високий рівень соціальної відповідальності.

Пропозиція на будівельному ринку - це бажання і можливість виробництва будівельної продукції, зумовлене потужностями будівельних організацій. Попит на будівельну продукцію - це бажання i можливість здійснити замовлення на будівництво об'єкту 3 визначенням терміну будівництва та його ціни, тобто сума укладених договорів і контрактів.

Зростання цін на ресурси, використовувані в будівництві, призвело до значного підвищення цін на будівельну продукцію і падіння попиту. У більшості населення не виявилося достатніх засобів на будівництво житла і придбання його на вторинному ринку. У результаті падіння об'ємів виробництва на промислових підприємствах і зміни відносин власності інвестиційні можливості господарюючих суб'єктів також знизилися. В умовах, що склалися, попит на будівельну продукцію виявився еластичним з таких причин:

- фізичні особи встали перед необхідністю зменшити свої потреби в житлі або задовольнити їх за рахунок ринку нерухомості;

- господарюючі суб'єкти в результаті повної відсутності відповідальності за технічний, технологічний, економічний i соціальний розвиток підприємства припинили інвестиційну діяльність;

- 3 боку держави не було вжито ніяких заходів для забезпечення замовленнями будівельних організацій і збереження їхніх потужностей.

Несприятливе економічне оточення будівельних організацій, проблеми переходу до нових економічних умов призвели до того, що практично будь-яка будівельна організація має нестійкий фінансовий стан. 


\section{1. Центральна ланка галузевих і територіальних \\ виробничих комплексів - будівельна організація}

Будівельна організація - це уособлена виробнича одиниця, основою якої $\epsilon$ професійно-організований трудовий колектив, здатний iз допомогою наявних у його розпорядженні засобів виробництва виробляти потрібну споживачеві будівельну продукцію (будинки, споруди, будівельні роботи) та будівельні послуги (ремонтнобудівельні роботи) відповідного призначення, профілю, типу. Це самостійна цілісна система технологічних, соціальних та економічних відносин, що виступають як господарська одиниця виробник будівельної продукції. Це самостійний суб'єкт матеріального виробництва та ринку, що має права юридичної особи.

Будівельна організація - відособлена виробничо-господарська одиниця, основним видом діяльності якої $\epsilon$ будівництво нових, реконструкція, капітальний ремонт і розширення діючих об'єктів, а також монтаж обладнання. Будівельна організація класифікується за видом робіт:

- загальнобудівельні організації - виконують комплекс основних видів монтажу, кам'яних, теслярських й інших масових робіт;

- спеціалізовані будівельні організації - виконують лиш один вид або комплекс однорідних робіт.

Виробничі структури будівельної організації визначаються складом i напрямком підрозділів, які здійснюють загальнобудівельні та спеціалізовані роботи; виготовляють будівельні конструкції та напівфабрикати; здійснюють експлуатацію i ремонт будівельних машин і механізмів.

Відповідно до чинного законодавства підприємство - це самостійно господарюючий суб'єкт, який виробляє продукцію, виконує роботи та надає послуги з метою задоволення громадських потреб та отримання прибутку.

Підприємство як юридична особа має відповідати певним вимогам, що встановлюються державою на законодавчому рівні, а саме:

- мати власне майно;

- нести самостійну майнову відповідальність;

- мати право бути позивачем та відповідачем від свого імені;

- мати самостійний бухгалтерський баланс, розрахунковий та інші рахунки.

Основні риси сучасного підприємства:

1. Випускає товари і забезпечує купівельну спроможність для їх споживання.

2. Підтримує розширення соціальної інфраструктури і забезпечує прибуток. 
3. Створює робочі місця на самому виробництві, у постачальників і в державному секторі.

4. Створює багатство, яке необхідне для власного розвитку.

5. Має численні зовнішні зв'язки з навколишнім середовищем.

Успіх фірми в значній мірі залежить від того, хто і як регулює і контролює зовнішні зв'язки.

Сучасна будівельна організація має всі основні риси підприємства, а caмe:

- організаційну єдність: будівельна організація - це певним чином організований колектив зі своєю внутрішньою виробничою структурою та порядком управління. Базується на ієрархічному принципі організації економічної діяльності;

- певний комплекс засобів виробництва: будівельна організація поєднує економічні ресурси для виробництва матеріальних благ із метою максимізації прибутку;

- майнову відповідальність: будівельна організація несе повну відповідальність усім своїм майном за різними зобов'язаннями;

- єдиноначальність: будівельна організація передбачає єдиноначальність, засновану на прямих адміністративних формах управління;

- самостійність: виступає в господарському обігу від власного імені (найменування), має самостійний баланс, розрахунковий та інші рахунки в банках, круглу печатку, дозвіл на виробництво будівельномонтажних робіт і реалізацію своєї продукції (будинків, споруд, робіт);

- оперативно-господарську й економічну самостійність: будівельна організація сама здійснює різні угоди й операції, сама отримує прибуток або несе збитки, за рахунок прибутку забезпечує стабільний фінансовий стан і дальший розвиток виробництва й іншої інфраструктури.

Таким чином, будівельна організація в сучасних умовах $\epsilon$ самостійним суб'єктом господарювання, фактично це - будівельне підприємство.

Під господарською діяльністю розуміють діяльність суб'єктів господарювання у сфері суспільного виробництва, спрямовану на виготовлення та реалізацію продукції, виконання робіт чи надання послуг вартісного характеру, що мають цінову визначеність.

Господарська діяльність, що здійснюється для досягнення економічних і соціальних результатів та з метою одержання прибутку, $\epsilon$ підприємництвом, а суб'єкти підприємництва - підприємцями. Господарська діяльність може здійснюватися і без мети одержання прибутку - це некомерційна господарська діяльність.

Внутрішнє середовище будівельної організації, як і підприємства люди, засоби виробництва, інформація та гроші. Результатом компонентів внутрішнього середовища є готова будівельна продукція. 
Зовнішнє середовище, яке безпосередньо визначає ефективність будівельної організації, - це насамперед споживачі будівельної продукції, постачальники виробничих компонентів, а також державні органи та населення, що проживає навколо будівельної організації.

У процесі виробничої діяльності будівельна організація піддається випадковому впливу зовнішнього середовища, яке характеризується певною інтенсивністю i дестабілізаційною здатністю. Остання проявляється у величині відхилення контрольних параметрів об'єкта управління від планового режиму їх розвитку.

Вузькоспеціалізовані підприємства мають обмежену сферу своїх виробничих інтересів у рамках вузької номенклатури виробів, комплексів робіт. Таким організаціям властиві відносно високий виробіток i низька собівартість. Але в разі сильних дестабілізаційних впливів зовнішнього середовища, через обмежену можливість маневру у сфері виробничої діяльності вони позбавлені можливості демпфірувати ці впливи, і об'єктом відповідної управлінської реакції стає вся організація. Чим більша така організація, тим у більшій мірі проявляється іï інертність у розмірі поведінки у відповідності з прийнятою стратегією виходу зі сфери негативного впливу зовнішнього середовища. Тому підприємства такого типу успішно функціонують в умовах регіонального (територіального) монополізму, відсутності серйозних зовнішніх і внутрішніх протиріч.

I на противагу вузькоспеціалізованим підприємствам $\epsilon$ ті, у виробничій діяльності яких не просліджується чітко виражена спеціалізація та $є$ широка сфера інтересів виробничої діяльності. У таких підприємствах, якщо й виникає сильний дестабілізуючий вплив, то він одночасно торкається всіх напрямів виробничої діяльності. Звідси слідує, що велика частина виробництва продовжує находитись у стабільному стані, що створює умови для можливості широкого маневру як за рахунок перерозподілу ресурсів, так і сфер діяльності. Якщо в одному 3 напрямів діяльності такі впливи за об'єктивних причин набирають хронічний характер, то крайньою мірою така організація може відмовитись від цього напрямку i перенацілити потужності на нові перспективні напрями. Очевидно, що цей тип організації більш гнучкий і здатний вижити в тих умовах, в яких вузькоспеціалізовані підприємства зазнають потрясіння, вийти 3 котрих без втрат вдається далеко не завжди ${ }^{1}$.

${ }^{1}$ Ващенко А.А. Ефективність виробничо-господарської діяльності в механізмі управління промисловими підприємствами. Наук. вісник Нац. гірн. університету : наук.-техн. журнал. 2014. № 1. С. 80. 
Найважливішими завданнями діючої будівельної організації є:

- отримання доходу власником будівельної організації;

- забезпечення споживачів (замовників) будівельною продукцією;

- забезпечення персоналу будівельної організації заробітною платою, нормальними умовами праці та можливістю професійного росту;

- створення робочих місць для населення, яке проживає біля будівельної організації;

- охорона навколишнього середовища: землі, повітряного та водного басейнів;

- недопускання перебоїв у роботі будівельної організації (зриву строків здачі об'єктів у експлуатацію, здача неякісних робіт, зниження обсягів виробництва та рентабельності).

Отримання прибутку $є$ надійним, якщо підприємству вдалося завоювати ринок, домогтися конкурентоспроможності продукції та забезпечити собі фінансову стійкість і платоспроможність. Це дає нам підстави стверджувати, що підприємству властиві дві найважливіші ознаки:

1. Ведення господарської діяльності з метою отримання прибутку та задоволення потреб суспільства;

2. Статус юридичної особи.

Таким чином, організації, що не здійснюють господарської діяльності й не ставлять фінансових цілей, не є підприємствами. До них не належать структурні відділення підприємства, громадяни, що займаються підприємницькою діяльністю без оформлення статусу юридичної особи, та громадські організації.

Виділяють такі типи організацій:

1. Цілевважаючі організації - самі по собі формують для себе цілі діяльності та змінюють їх на основі досягнутих результатів власної еволюції і зміни середовища. Цей тип у найбільшій мірі відповідає організаціям, які діють в умовах ринкових відносин і самостійно розробляють господарську стратегію свого розвитку;

2. Цілеспрямовані організації - діють у відповідності 3 чітко сформульованими i заданими цілями. Такому типу відповідають організації, які находяться в системі планування й адміністративного регулювання або ж у державній структурі, або в системі деякої цілевважаючої організації, якій делеговані відповідні права;

3. Цілеорієнтовані організації - мають чітко сформульовані цілі, які можуть у певних межах видозмінюватися самою організацією. У такому режимі працюють організації, які входять у господарськорахункові договірні агреговані управлінські структури, наприклад, типу концерн. 
4. Задовільняючі організації - мають короткочасні цілі у вигляді разових завдань надсистеми. Ці організації створюються для реалізації конкретних цільових програм і утворюють агреговані структури типу консорціуму.

5. Паразитичні організації - мають ціль діяльності, безкорисну для надсистеми, окрім того, вони споживають іiі ресурс.

Це можуть бути організації, які мають власну ефективність діяльності, але яка слабо позначається на ефективності надсистеми. Тому такі організації повинні бути надсистемою відторгнені для подальшої самостійної діяльності.

На основі розглянутих типів організацій побудовано блок-схему (Рис. 1) їх класифікації з урахуванням деяких визначальних факторів.

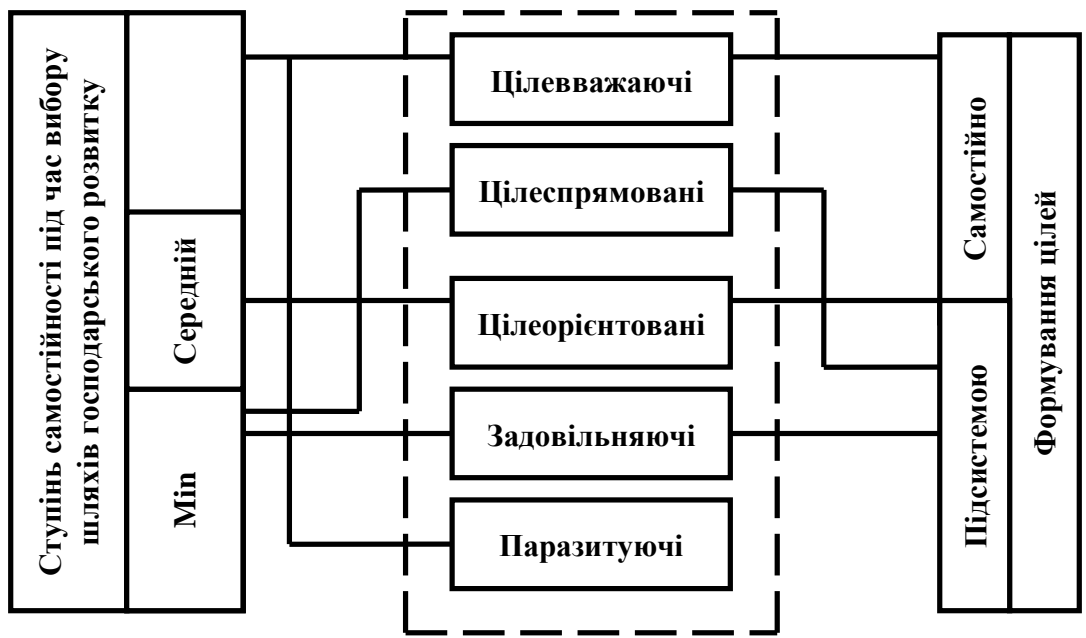

Рис. 1. Блок-схема класифікації типів організацій

Класифікація структур будівельних підприємств і фірм:

- за видами власності: приватні; державні; змішані;

- за характером використовуваного капіталу: інтелектуальний; матеріальний; змішаний;

- за формуванням оборотних коштів: власні; позикові; ті, що авансуються замовником;

- за територіальною ознакою: місцеві; не місцеві (зокрема, іноземні);

- за часом функціонування: постійні; тимчасові; невизначені;

- за статусом: генпідрядні; субпідрядні; змішані;

- за спеціалізацією: промислові; цивільні; універсальні. 
Завдання будівельної організації визначаються:

- інтересами власника;

- розмірами капіталу;

- ситуацією всередині будівельної організації;

- зовнішнім середовищем.

Право постановки завдання перед персоналом будівельної організації залишається за власником незалежно від його статусу приватна особа, державні органи чи акціонери.

Найважливішим завданням будівельної організації $\epsilon$ отримання доходу за рахунок реалізації споживача (замовника) будівельної продукції (виконаних робіт, наданих послуг).

Незалежно від форм власності будівельна організація працює, як правило, на умовах повного господарського розрахунку, самофінансування. Вона самостійно укладає договори (контракти) із замовником, зокрема отримує державні замовлення, а також укладає договори та веде розрахунки з постачальниками потрібних виробничих ресурсів ${ }^{2}$.

Функції будь-якого підприємства знаходять своє відображення в системі його цілей, що містить такі головні складники:

1) задоволення потреб персоналу підприємства;

2) удосконалення структури підприємства, іiі адаптація до внутрішніх та зовнішніх змін;

3) створення та підтримка потенціалу для майбутнього розвитку, безперервності існування підприємства;

4) задоволення зовнішніх вимог до підприємства та пред'явлення власних вимог до навколишнього середовища.

Лише одночасно здійснюючи реалізацію всіх цілей, підприємство здатне функціонувати та розвиватися. Такий підхід визначає підприємство як унікальний соціально-економічний феномен, здатний, по-перше, забезпечити суспільні потреби i, по-друге, реалізувати органічну єдність виробничих та відтворювальних процесів.

Основні функції будівельної організації такі:

- будівництво будинків і споруд виробничого і невиробничого призначення, а також особистого користування;

- продаж і своєчасна здача в експлуатацію об'єктів будівництва;

- матеріально-технічне забезпечення будівельного виробництва;

- управління й організація праці персоналу будівельної організації;

2 Жуков А.В. Місце збалансованої системи показників у діагностиці ефективності виробничо-господарської діяльності підприємства. Комун. госn. міст : наук.-техн. зб. Харків : Вид-во Харків. НУМГ ім. О.М. Бекетова. 2013. Вип. 108. C. 228. 
- розвиток i зростання обсягів виробництва будівельної організації;

- підприємництво;

- сплата податків, перерахування обов'язкових та добровільних внесків і платежів у бюджет та інші фінансові органи;

- дотримання діючих норм, стандартів, нормативів, державних законів.

Добре організована структура дає більший ефект, ніж впровадження нової технології або устаткування. Ефективність забезпечується стратегією, а результативність - тактикою.

Основні вимоги до підприємств і організацій в умовах ринку:

1. Гнучкість і здатність швидко змінювати асортимент виробів.

2. Забезпечувати право свободи діяльності на основі розширення горизонтальних зв'язків.

3. Вміння прогнозувати і своєчасно виконувати зміни.

4. Враховувати затрати на вироблення продукції і ціни, а також затрати споживачів на експлуатацію і використання.

5. Виробляти продукцію високої якості.

6. Піклуватись про післяпродажне обслуговування.

7. Вивчати попит і завойовувати ринок.

8. Нарощувати діяльність з ефективного збуту продукції.

9. Забезпечувати нарощування оборотних коштів (спосіб заміни).

10. Орієнтуватися на саморозвиток і самозабезпечення.

В умовах ринкових відносин необхідні:

1. Режим експерименту й експериментування.

2. Розподіл ресурсів шляхом внутрішньої конкуренції.

3. Дроблення організації на малі технологічно допустимі відособлені осередки (випуск різної продукції).

4. Безперервний контакт зі споживачем усіх працівників.

5. Орієнтація на швидкі та енергійні дії (для цього необхідні: матеріальні можливості, знання про те, що треба робити, стимули).

6. Автономія, яка підтримує заповзятливість.

7. Орієнтація на 1-2 цілі.

8. Робити те, що добре знаєш і вмієш.

9. Поєднання свободи і відповідальності за здоров'я людей, охорону навколишнього середовища. Підтримка талантів і культури.

\section{2. Наукові засади формування економічної стійкості}

\section{будівельних організацій}

Управління економічною стійкістю підприємства представляє собою комплексний процес, який реалізується через функції організації, планування, обліку, контролю, мотивації. Взаємозв'язок і 
взаємодія цих функцій i етапів процесу управління визначають цілісність системи управління підприємством.

Економічна стійкість підприємства формується в процесі виробництва, а забезпечується і підтримується на етапах реалізації і розподілу продукції. Це визначає наявність двох функціональних складників: виробничо-технічної стійкості (включається стійкість техніко-технологічного рівня, стійкість кадрового складу, стійкість організації виробництва) і фінансово-економічної стійкості (включає фінансову стійкість, стійкість рівня рентабельності і стійкість ділової активності).

В умовах конкуренції найважливішою стратегією будівельного підприємства є забезпечення його стійкого розвитку.

Оцінка стійкості будівельних підприємств грунтується згідно 3 порівнянням економічної вигоди i економічних витрат. Під економічними вигодами тут розуміється збільшення справжніх i майбутніх грошових потоків, а під економічними витратами зменшення справжніх і майбутніх грошових потоків.

Зміна кон'юнктури ринку, конкуренція й інші внутрішні та зовнішні чинники можуть привести як до позитивної, так і до негативної зміни стійкості підприємства. Тому стійкість слідує розглядати як системне, а не випадкове явище ${ }^{3}$.

Найважливішим інструментом управління економічною стійкістю підприємства є моделювання. Воно дозволяє аналізувати та прогнозувати економічну ситуацію всередині підприємства i за його межами, ринки збуту і матеріально-технічних ресурсів. У процесі моделювання здійснюється попереднє вивчення об'єкту 3 метою виділення його істотних характеристик, конструювання моделі, аналіз адекватності моделі реальним економічним процесам і її коректування.

Модель економічної стійкості будівельного підприємства 3 розкриттям наведеної нерівності наведена на Рис. 2.

Модель містить усі грошові потоки, необхідні для виробничого бізнесу, і відображає три сфери діяльності, по яких ухвалюються рішення: інвестиційну, виробничу і фінансову.

Інвестиційну діяльність характеризують існуюча інвестиційна база, нові інвестиції, вилучення вкладень, які більш не $є$ необхідними; виробничу - змінні й постійні витрати, об'єм реалізації продукції і ціна; фінансову - прибуток, власний капітал, дивіденди, відсотки по кредитах, довгострокова заборгованість і потенціал, який створюється для інвестування розвитку.

${ }^{3}$ Примуш Ю.С. Аналіз життєвого циклу будівельної галузі України. Крим. екон. вісник : зб. наук. праць. 2013. № 1(02). С. 10. 
В основі моделі стоїть обмежена єдність усіх трьох видів діяльності, яка забезпечує необхідні й достатні умови економічної стійкості будівельних організацій.

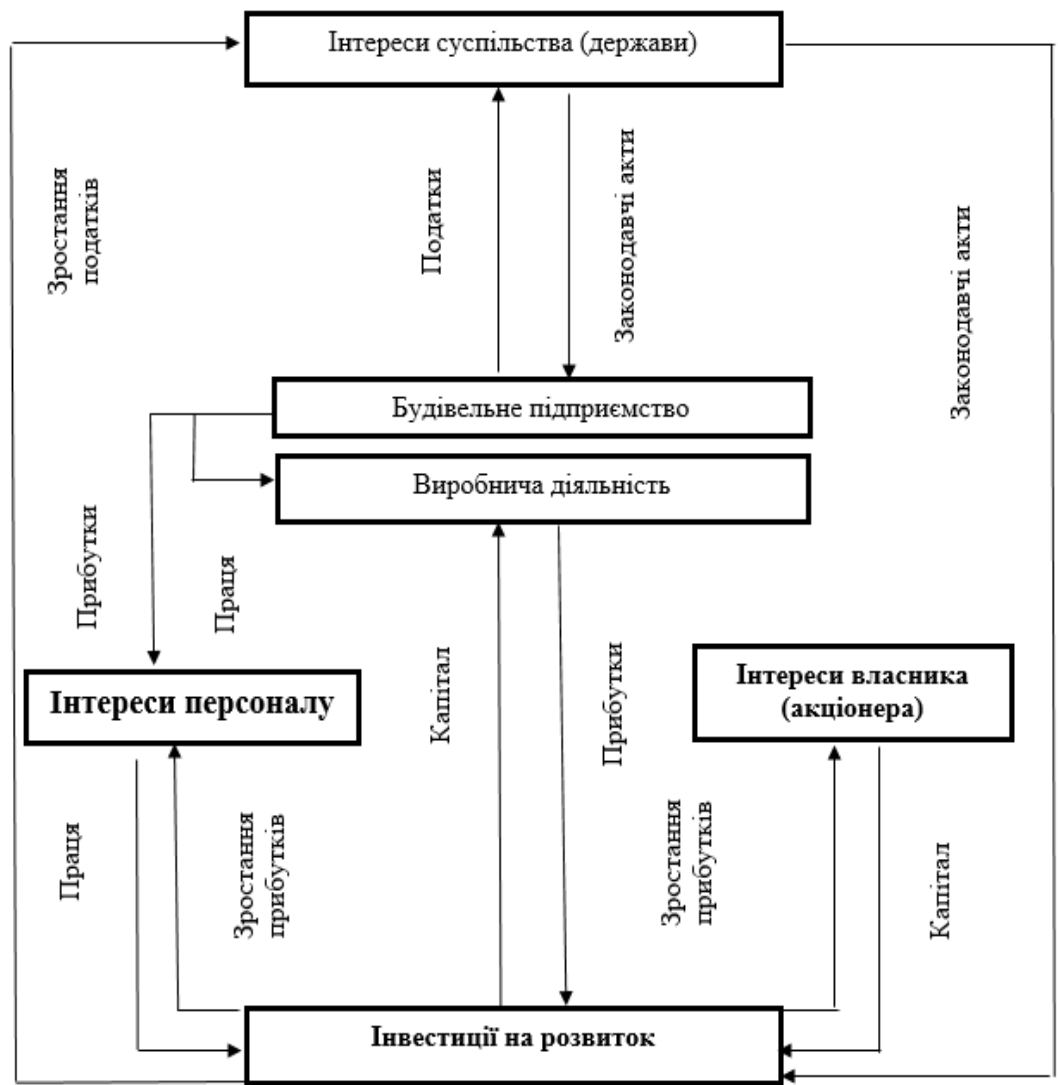

Рис. 2. Модель економічної стійкості будівельної організації

Найважливішими напрямами підвищення стійкості підприємства $є$ : формування достатньої виробничої програми, організація постачання матеріалів і виробів, оперативне управління виробництвом, організація реалізації продукції, освоєння конкурентоздатної продукції, управління проектами реструктуризації виробництва, управління інвестиціями.

Для визначення динаміки зміни показника стійкості будівельного підприємства пропонується така методика його оцінки.

Початковою передумовою до вибору критеріїв оцінки стійкості будівельного підприємства $є$ встановлення ключових аспектів його 
діяльності. Визначення видів діяльності значною мірою залежить від розмірів і положення підприємства на ринку. Перш ніж приступити до встановлення ключових аспектів діяльності, необхідно визначити місію підприємства, тобто уявлення підприємства про своє майбутнє.

Місія - головна мета підприємства, ради якої воно було встановлене, і якій підлегла його діяльність. Іншими словами, це значення існування підприємства як спосіб задоволення певної потреби суспільства, яку підприємство може забезпечити, вибір ніші й сегменту ринку.

Місія підприємства включає як внутрішні, так і зовнішні орієнтири його діяльності, виражає суть його успіху, якого повинна добитися організація. Правильно сформульована місія служить основою вибору цілей і стратегій.

Цілі підприємства визначають результат діяльності і шляху його досягнення за допомогою певних засобів. На відміну від місії, вони виражають окремі конкретні напрями діяльності підприємства.

Для досягнення намічених цілей розробляється стратегія, в якій відображається сукупність дій, що дозволяють устояти підприємству в конкурентній боротьбі й досягти намічених цілей. Під стратегією розуміється узагальнена модель дій, необхідних для досягнення поставлених цілей шляхом координації $\mathrm{i}$ розподілу ресурсів підприємства. Фактично стратегія - це вибір правил для ухвалення рішень, якими організація керується у своїй діяльності, забезпечуючи загальний напрям досягнення стійкості.

Розглядаючи функціонування підприємства 3 позиції його стійкості, можна виділити чотири ключові аспекти діяльності: фінансова діяльність, відносини зі споживачами, організація внутрішніх бізнеспроцесів, зростання і розвиток.

Кожний із цих аспектів є, з одного боку, сферою впливу самого підприємства, а з іншою - сферою впливу зовнішнього середовища. Тому необхідно розглядати взаємодію і взаємовплив цих сфер під час визначення для кожної з них параметрів, за яких виробничо-фінансова діяльність підприємства матиме максимальну стійкість. За кожним ключовим аспектом діяльності підприємства необхідно визначити конкретні стратегічні цілі й виявити найістотніші 3 погляду місії чинники, що сприяють досягненню поставлених цілей.

Для визначення впливу чинників на досягнення поставлених цілей щодо кожного чинника розробляється система збалансованих показників і визначаються їхні значення, за яких виробничо-фінансова діяльність підприємства матиме максимальну стійкість. Для виявлення інтегрального показника стійкості підприємства необхідно проранжирувати чинники, встановити причинно-наслідкові зв'язки між 
чинниками і характерні їхні показники. Встановлення чинників та їхніх показників є базою для визначення показників стійкості.

Таким чином, під стійкістю підприємства слід розуміти наявність інноваційного потенціалу стійкого розвитку i його ефективне використовування для нейтралізації зовнішніх дій $і$ чинників дестабілізації. Таке визначення стійкості підприємства дозволяє оцінити ii кількісно, що у свою чергу дає можливість управляти іiі рівнем ${ }^{4}$.

Оцінку стійкості, на нашу думку, слід проводити по групах показників, що відносяться до певного чинника і характеризують ключові аспекти діяльності підприємства. При цьому аналізовані показники повинні відповідати таким вимогам, як: економічна обгрунтованість і об'єктивність, можливість формалізації чисельного розрахунку, конкретність і однозначність тлумачення одержуваних результатів, узгоджена зміна показників взаємозв'язаних груп у часі.

\section{3. Роль держави в ринковій діяльності будівельних організацій}

В умовах переходу економіки країни на ринкові засади господарювання необхідний подальший розвиток i удосконалення Системи нормативно-правового забезпечення будівництва Україні, яка повинна формуватися на чітко визначеній методологічній основі та мати виважену обгрунтовану структуру. Провідна роль у вирішені даної проблеми повинна належати державі. (Згідно зі статтею 9 Закону України «Про засади державної регуляторної політики у сфері господарської діяльності»).

Важливою характеристикою будівельної організації, яка визначає форму іiі економічної діяльності, $\epsilon$ ступінь економічної свободи (самостійність). При цьому необхідно мати на увазі, що абсолютної економічної свободи ні в якій державі не існує.

Повна економічна свобода на базі приватної власності виявляється у:

- повній самостійності будівельної організації: розпорядженні виробленою продукцією, отриманим прибутком, установленні цін на продукцію (роботи), заробітної плати, виборі партнерів тощо;

- наявності, поряд із загальною метою - максимізацією прибутку, локальних цілей виробництва: забезпечення виживання, завоювання ринку та інше.

Відносна економічна свобода на базі державної та муніципальної власності виявляється в:

4 Рудницька О.М., Петльована О.О. Удосконалення виробничо-господарської діяльності будівельних підприємств. 3б. наук.-техн. пращь. «Львівська політехніка». 2014. C. 290. 
- обмеженій самостійності будівельної організації, що регламентується контролюючим відомством та урядом;

- обмеженій відповідальності будівельної організації, що виражається в державній підтримці у формі дотацій, субсидій, пільг в оподаткуванні тощо;

- підпорядкуванні мети виробництва економічним цілям (інтересам) держави.

Принципову схему управління й регулювання будівельної організації у ринкових умовах господарювання подано на Рис. 3.

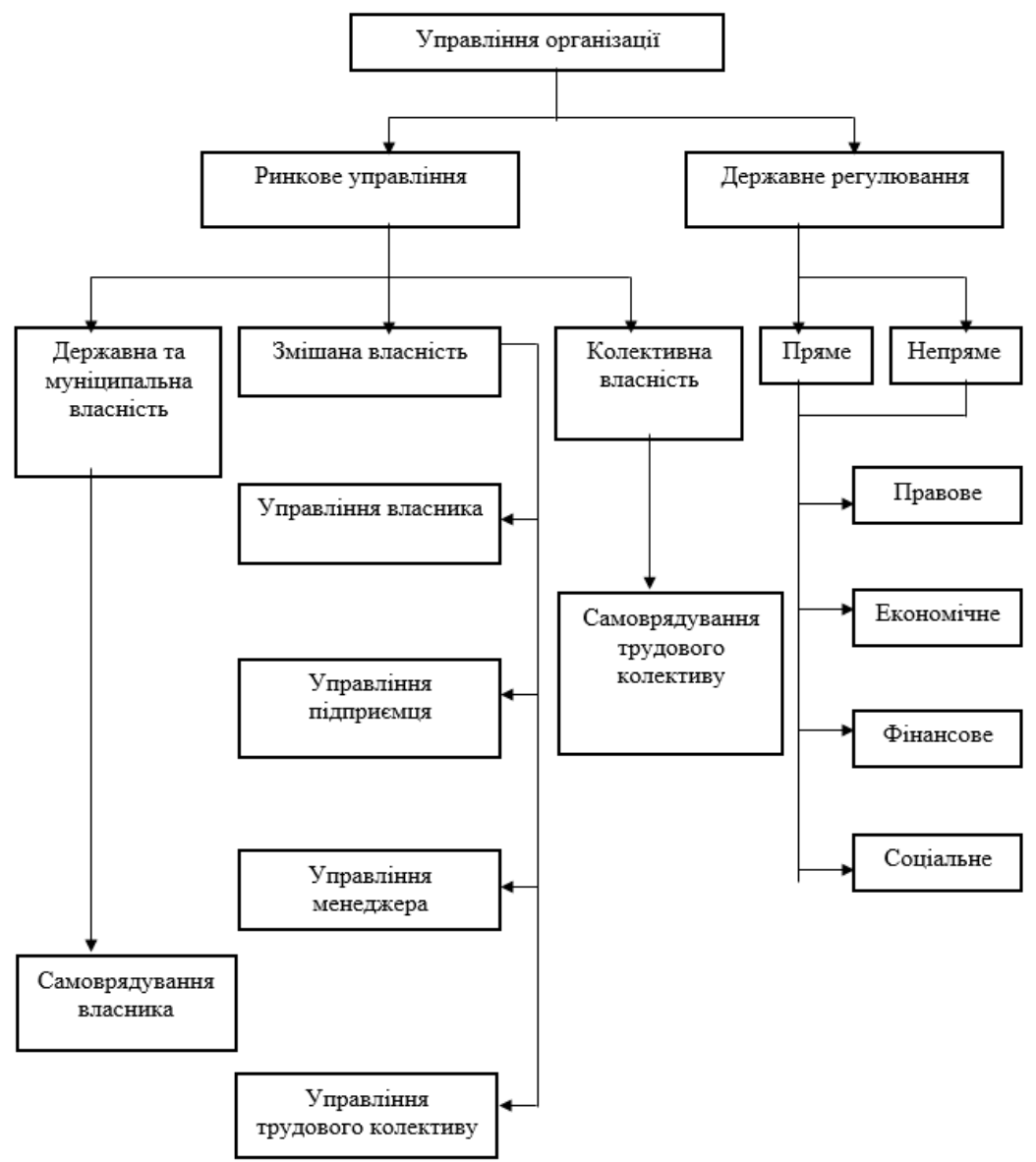

Рис. 3. Принципова схема управління будівельної організації в умовах ринку 
Усі будівельні організації (як приватного, так і державного сектора економіки) у процесі функціонування діють у межах певних законів, правових норм, тобто в системі правових відносин.

Система управління будівельною організацією залежить насамперед від того, за якою організаційно-правовою формою зареєстрована організація, та які важелі державного регулювання на неї впливають.

Більш складна система управління організації у випадку, коли $є$ змішана власність і навіть колективна власність, де власників багато, наприклад, акціонерне товариство відкритого типу.

Стан галузі й позиція будівельного підприємства в галузі найчастіше можуть грати вирішальну роль у виборі стратегії росту будівельного підприємства. Сильні будівельні підприємства повинні прагнути максимального використання можливостей, породжуваних їхнім провідним положенням, і зміцнення цього положення. Слабкі будівельні підприємства повинні вибирати ті стратегії, які можуть призвести до збільшення їхнього потенціалу. Якщо ж таких стратегій немає, то вони змушені покинути цей сектор ринку.

\section{ВИСНОВКИ}

Аналіз виробничо-господарської діяльності будівельних організацій $\epsilon$ однією 3 форм економічної діяльності, має метою вивчення роботи будівельних організацій, встановлення причин відхилень від планових завдань, виявлення виробничих резервів. Аналіз $\epsilon$ підставою для розроблення заходів щодо поліпшення діяльності будівельних організацій.

Проблема вдосконалення виробничо-господарської діяльності будівельних підприємств досі залишається недостатньо розкритою. Потребують подальшого дослідження шляхи покращення виробничогосподарської діяльності будівельних підприємств. Виходячи 3 цього, актуальними $є$ подальші наукові дослідження виробничо-господарської діяльності підприємств.

\section{АНОТАЦІЯ}

Досліджено економічну сутність такого поняття, як «виробничогосподарська діяльність підприємства» та проаналізовано різні наукові підходи до трактування терміна. Визначені вимоги, яким має відповідати будівельне підприємство, що встановлюються державою на законодавчому рівні. Представлена блок-схема класифікації типів організацій. Відображені основні функції будівельного підприємства в системі його цілей. Представлена модель економічної стійкості будівельного підприємства. Досліджено ефективність виробничогосподарської діяльності та іiі місце в механізмі управління підприємством. Визначено, яким чином потрібно спрямовувати на всебічне задоволення потреб споживачів. 


\section{ЛITЕРАТУРА}

1. Ващенко А.А. Ефективність виробничо-господарської діяльності в механізмі управління промисловими підприємствами. Наук. вісник Нац. гірн. університету. : наук.-техн. журнал. Дніпропетровськ : Вид-во НГУ, 2014. № 1. С. 80-86.

2. Жуков А.В. Місце збалансованої системи показників в діагностиці ефективності виробничо-господарської діяльності підприємства. Комун. госп. міст : наук.-техн. зб. Харків : Вид-во Харків. НУМГ ім. О.М. Бекетова, 2013. Вип. 108. С. 228-235.

3. Примуш Ю.С. Аналіз життєвого циклу будівельної галузі України. Крим. екон. вісник : зб. наук. праць. 2013. № 1(02). С. 10-15.

4. Рудницька О.М., Петльована О.О. Удосконалення виробничогосподарської діяльності будівельних підприємств : зб. наук.-техн. праць. Львів : «Львівська політехніка». 2014. С. 290-296.

\section{Information about the authors: Kornylo I. M., Candidate of Economic Sciences, Associate Professor at the} Department of Organization of Construction and Safety Odessa State Academy of Civil Engineering and Architecture 4, Didrihsona str., Odesa, 65029, Ukraine Gnyp O. P., Candidate of Technical Sciences, Associate Professor at the Department of Processes and Apparatus in the Technology of Building Materials Odessa State Academy of Civil Engineering and Architecture 4, Didrihsona str., Odesa, 65029, Ukraine 